\title{
Ambulatory Visit
}

National Cancer Institute

\section{Source}

National Cancer Institute. Ambulatory Visit. NCI Thesaurus. Code C154474.

A visit to an ambulatory care facility. 